\title{
Loyalty program value: Give me more or treat me better?
}

\author{
Piotr Kwiatek $^{1}$, Vladimir Dženopoljac ${ }^{2 *}$, Abdul Rauf ${ }^{3}$ \\ ${ }^{1}$ Kozminski University, Marketing Department, Poland \\ ${ }^{2}$ United Arab Emirates University, College of Business and Economics, UAE \\ ${ }^{3}$ Wittenborg University of Applied Sciences, Apeldoorn, The Netherlands
}

\begin{abstract}
Customer loyalty programs are frequently used by companies to establish and improve relationships with customers by providing them with rewards. Loyalty programs investigated in the literature focus mainly on tangible rewards and economic benefits offered to the cus tomers. However, some research done on intangible rewards of loyalty programs suggest that they can be superior to tan gible benefits in affecting customer loyalty. Previous research drew conclu sions in industry-specific settings. The aim of the paper is to ass ess the impact of tangible and intangible benefits on customer loyalty using an on-line customer panel representing different industries. The data collected from over 300 customers is subjected to CFA/SEM analys is in R environment. The main contribution of the present study is that it represents the first attempt (to the best of authors' knowledge) to capture loyalty programs' tangible and intangible value in an Arab cultural context, given the fact the focus was on the participants from the United ArabEmirates. Several important dimensions of LP programs in an Arab country are revealed. Firstly, the study confirmed that social value of a loyalty program significantly impacts customer loyalty. In addition, it was confirmed that the flexibility of a loyalty programincreased cus tomer loyalty. Ultimately, it was established that customers value intangible benefits more than the tangible ones.
\end{abstract}

Keywords: loyalty program value, economic value, social benefits, intangible benefits, tangible benefits

JEL classification: M31

\section{Vrednost programa lojalnosti: Daj mi više ili me tretiraj bolje?}

Sažetak:Kompanije čes to koris te programe lojalnosti kako bi razvili i unapredili odnose sa svojim kupcima, uz obezbeđivanje različitih nagrada. Programi lojalnosti koji s u is traženi u literaturi se najčešće fokus iraju na opipljive nagrade i ekonomske koris ti koje se kupcima nude. Međutim, određene is traživačke studije koje su se bavile neopipljivim nagradama programa lojalnos ti sugerišu da upravo neopipljive koris ti mogu biti superiornije u odnosu na opipljive i efektivnije u obezbeđivanju lojalnosti kupaca. Većina ranijih istraživanja je

*vdzenopoljac@uaeu.ac.ae

This article is an open access article distributed under the terms and conditions of the Creative Commons Attribution (CC BY) license (http://creativecommons.org/licenses/by/4.0/). 
analizirala konkretne privredne grane. U ovom radu istražuje se uticaj opipljivih i neopipljivih koris tina lojalnost kupaca, uz upotrebu panela kupaca iz različitih privrednih grana. Podaci su prikupljeniod viš e od 300 kupaca i analizirani su uz pomoć CFA/SEM u R okruženju. Glavni doprinos is traživanja se sastoji u tome da, koliko je autorima poznato, ova studija predstavlja pionirski pokušaj obuhvatanja opipiljivih i neopipljivih benefita programa lojalnos ti u kontekstu jedne arapske države, tj. Ujedinjenih Araps kih Emirata. Istra živanje je ukazalo na bitne dimenzije programa lojalnos ti kod kupaca u jednoj arapskoj zemlji. Studija je prvenstveno potvrdila da društvena vrednost programa lojalnosti značajno opredeljuje lojalnost kupaca. Pored ovoga, is traživanje je potvrdilo da fleksibilnost programa podiže lojalnost kupaca. Na kraju, utvrđenoje da kupciu većoj meri vrednuju neopipljive ko risti od programa lojalnosti u odnosu na opipljive.

Ključne reči: vrednost programa lojalnosti, ekonomska vrednost, društvene koristi, neopipljive koristi, opipljive koristi

JEL klasifikacija: M31

\section{Introduction}

Companies tend to capitalize from their relationships with external stakeholders and therefore invest significant efforts in relational capital, which captures knowledge embedded in organizations relationships with customers, suppliers, creditors, and other external partners (Gunay et al., 2021). Loyalty programs (LPs) are one of the main marketing tools companies implement to nouris h customer loyalty, both in B2C (Kwiatek et al., 2018) and B2B markets (Kwiatek \& Thanasi-Boçe, 2019). Ha and Stoel (2014) define a loyalty program as an "identity marketing tool" which is based on providing customer with rewards. Stein hoff and Palmatier (2016) define LPs as "any institutionalized incentive system that attempts to enhance consumers' consumption behavior over time" LPs are used by companies not only to increase sales, but also to create long-lasting (Yi \& Jeon, 2003) and stronger (Uncles et al., 2003) relationships with customers. In attempts to increase customers' engagement in LPs, companies emphasize the LP value and the potential benefits customers might gain thanks to a LP. LPs are presented in the literature as the main tool to build customer loy alties (Buhalis \& Volchek, 2021; Hollebeek et al., 2021). From the customer's perspective, LP value is referred to as a bundle of perceived benefits (Zakaria et al., 2014). This bundle consists of tangible (i.e. economic) value the customers gather such as monetary savings (Kopalle et al., 2012), and intangible (soft) benefits such as psychological value (Liu, 2007). The higher perceived value of a loyalty program, the stronger customer's response is (Kopalle et al., 2012; Yi \& Jeon, 2003). Certainly, it is an imperative for success ful management of a LP to develop a compelling set of benefits for customers.

The recent research on this topic appears to present inconclusive results. For example, tangible benefits strongly affect the customer satisfaction with a loyalty program, while intangible benefits, like being personally recognized, do not have significant effects (Mimouni-Chaabane \& Volle, 2010). On the contrary, Brashear-Alejandro et al. (2016) find that cus tomer recognition and social value (i.e., belonging to a social network) are the soft benefits that positively affect customer-company identification and thus strengthen the bonds that brands form with customers. It is also worth noting that previous research was limited and carried out in industry-specific context, like retail (Mimouni-Chaabane \& Volle, 2010) and hospitality (Kim et al., 2013). Thus, the purpose of the current study is to compare tangible and intangible benefits for cus tomers or (both customer and companies) of a LP and assess their relative impact on customer loyalty outside of any industry -specific context. 


\section{The ore tical background}

\subsection{Specifics of loyalty programs in the hospitality industry}

A couple of decades ago leading hospitality companies started introducing a range of LPs to enhance their relationships with the guests. The fundamental premise which led to such initiatives' popularity were mainly because of an understanding that "loyal cus tomers exhibit long-termcommitment to the brand, leading to increased buying intention, higher revenue per customer; a willingness to pay more for comparable products/services; and reduced vulnerability to substitution by alternative brands" (O'Connor, 2021). Moreover, since loyalty of customers represents one of the key objectives of any organization (whether product or service oriented), achieving customer satisfaction is seen as the most important prerequisite for this. In order to achieve customer satisfaction, there should be a positive difference between anticipated expectations and realized service experience (Jevtić et al., 2020). The customer loyalty is also seen as an important part of intellectual capital, more specifically, relational capital of hotels, which is considered to have a major value creating effect for these organizations (Bontis et al., 2015). The LPs are a significant factor of customer loyalty, which in turn create satisfied guests who are more satisfied and thus more loyal. This in turn, causes repeated visits and positive word-of-mouth. All these factors have significant positive impact on hotel profitability (Vujić et al., 2019).

LPs have never been as relevant as they are in recent time as hospitality giants such as, the American Airline, Hilton and Marriott have seen that LPs' effectiveness is important for overcoming recent global cris is invoked by Covid-19 pandemic (Pascual \& Cain, 2021). This assertion could be attributed to the growing competition, increasingly informative customers, emphasis on service quality perception, price, and satisfaction (Arora \& Narula, 2018; Dewitte et al., 2021). It has become more obvious, that in the hos pitality sector certain critical factors, such as innovative busines s model, "s haring economy" and collaborative commerce enabled by technological advancement of digital platform, have dis rupted the traditionalway of doing business (Altinay \& Taheri, 2019; Kuhzady et al., 2021; Lima \& de Ass is Carlos Filho, 2019; Sigala, 2017). These dis ruptions came at a low operational cost, and also are linked to the constant changes in the customer buying behaviors in this sector (Satti et al., 2020).

LP normally stems froma place of customer acquisition and retention strategies, and as a result of intense competition. Additionally, in the hos pitality industry, service quality, price perception and customer satisfaction are seen as factors responsible for customers embracing loyalty practices (Sattiet al., 2020). Hospitality sector falls more within the ambit of service industries. Servicequality has been identified as the predominant factor of satisfaction and loyalty among customers (Arora \& Narula, 2018). Although these researchers suggest that, achieving service quality is dependent on a number of elements such as time and situation, during Covid-19 pandemic, LPs facilitated and maintained loyal customers in the hos pitality sector (Pascual \& Cain, 2021). It is also important to note the challenges associated with LPs. For example, such programs' benefits may not be sustainable since they could easily be replicated by competitors as most of themare either identical or there is hardly any cost for the customers to switch (Premayani et al., 2018).

Businesses now prefer to maintain existing customers as it is presumed to be cost effective to retain than putting huge efforts and investment to attract new ones (Arora \& Narula, 2018). The existing customers retention has advantages as is argued that loyal customers become insensitive to prices, have built attachment to their preferred brand, all of which reduce costs of advertisement as well as marketing (Lentzet al., 2021). A proper application of LPs in the hospitality industry is said to be effective in profit maximization and sustainability, as it 
assists businesses to maintain competitive advantage and generate more revenue due to repeat visits from loyal customers (Lentz et al., 2021).

Kim et al. (2021) highlight LP dynamics for understanding the operational, psychological and design characteristics supporting the different stages/levels the customer experiences in such a relationship. It begins with the cognitive value assessment, in which the customer identifies the monetary benefits of such a LP. It goes through an emotional value characterized with an exclusive bond between the company and the customer (Kim et al., 2021). The cognitive and emotional elements are delicate in such relationship considering the four stages normally a customer experience (i.e., acquisition, onboarding, expansion, and retention) (Kim et al., 2021; Pascual \& Cain, 2021). Other researchers havenoted importance of LP, since these programs in the hos pitality sector helped companies' bond and build customer relation as they are used to stimulate and promote comeback buying behaviors which comes from a place of value adding (Chen et al., 2021).

\subsection{Loyalty program value}

A number of conceptualizations present the value and utility of the loyalty program from different pers pectives (Nes set et al., 2021). O'Brien and Jones (1995) broadly conceptualized loyalty programvalue as a composition of five elements: (1) monetary value of redemption rewards, (2) the scope of these different rewards, (3) the rewards' as pirational value, (4) the perceived prospect of realizing rewards, and (5) the LP's ease of use. This conceptualization builds on both objective (cash value, redemption choice) and subjective (ease of use, aspirational value, attainability of a reward) components of value. Als hurideh et al. (2020) presented a comprehensive analysis of the various benefits in this regard.

In a comparative study Kwiatek et al. (2018) show that benefits offered in a loyalty program are the most important element of loyalty program value. Supposed benefits could provide rationale why customers take part in loyalty programs, because these benefits increase loyalty and strengthen the relationship with the company (Bolton et al., 2004). Earlier research studies suggest that the customer benefits from a loyalty program entail utilitarian benefits (monetary savings and convenience), hedonic benefits (exploration and entertainment), and symbolic benefits (recognition and social benefits). Mimouni-Chaabane and Volle (2010) used hedonic-utilitarian-symbolic triad to derive more specific list of subjectively perceived benefits. In similar line, Evanschitzky et al. (2012) proposed three components of loyalty program value, namely social value, special treatment (both representing intangible value), and programvalue (economic). These days there are hardly any hos pitality companies without a loyalty programfor their customers (Lentz et al., 2021). Given the increased importance hospitality sector placed on LPs becau se of pres umed value, a sound understanding of the effectiveness of such LPs is necessary for key stakeholders. This paper attempts to answer the question to what extent intangible effects of LPs contribute to the level of customer loyalty.

\subsection{Hypothes es development}

SocialExchange Theory (SET) suggests that an individual's behavior varies depending on the exchange process of material goods, services, or social value with the company (Homans, 1961). Every party's aim in an exchange relationship is to minimize costs and maximize benefits. If cus tomers get more engaged in a LP, they may expect social gratification, with social status being an example of this gratification. The premise of a reward forcustomers to feel recognized and appreciated, their behavior is likely to endure and enhance their relationship. SET provides an economic framework for the analys is of noneconomic social 
situations (Chen et al., 2021). According to Blau, "engaging in ongoing social exchanges can create a platformof trust that facilitates the development of close relationships"(Blau, 1964).

The relationship links between customers and a company are positively affected by recognition (Alshurideh et al., 2020; Melancon et al., 2011). It creates customers' awareness of a higher status that moves them forward to a positive relationship outcome (Drèze \& Nunes, 2011). Subsequently, customers would amplify their attempts to maintain this position and demonstrate the higher status (Tanford, 2013). Thus, if customers feel special and are recognized, they should respond with higher loyalty. In line with SET and previous research (Kwiatek \& Thanasi-Boçe, 2019; Liu, 2007; Mimouni-Chaabane \& Volle, 2010), the anticipated outcome is that economic value also affects perceived LP value. In conclusion, we propose the following hypotheses:

H1: Intangible value, i.e. a) psychological value, and b) social value of a loyalty program positively affects customer loyalty

H2: Tangible value, i.e. a) economic value, and b) flexibilityofa loyalty program positively affects customer loyalty

\section{H3: Intangible benefits affect loyalty more than tangible benefits}

\section{Methodology}

Loyalty program value was conceptualized based on Kim et al. (2013), i.e., with two subdimensions for tangible value (economic value and flexibility), and two subdimensions for intangible value (social value and recognition). Building on previously validated scales, each subdimension was described and measured using 3-items Likert-type scales (Evans chitzky et al., 2012; Kim et al., 2013).

The targeted sample for this study was active loyalty program members who belong to consumer programs. We used customer panel managed by YouGov, a well-established consumer panel boasting 11 million members worldwide. For the purpose of the current study, we concentrated on members that represent the population of the United Arab Emirates (UAE) and are at least 18 years old. Members of the panel were invited to participate in an online survey using a quantitative questionnaire and offered a pos sibility to enter a draw for rewards upon completing the survey. All items were measured using 7-point Likert-type scales $(1=$ strongly dis agree to $7=$ s trongly agree). The recognition component on a scale provided by Hennig-Thurau et al. (2002), and Evans chitzky et al. (2012). Social value component measurement was based on symbolic dimensions and adopted from (So et al., 2015). Program's flexibility was based on Xiong et al. (2014), and economic value on So et al. (2015).

The loyalty towards the LP scale comprised of attitudinal items (Baloglu, 2002); (Evans chitzky et al., 2012), behavioral items (Omar et al., 2010; Umashankar et al., 2017; Xiong et al., 2014), and recommendation items from Raab et al. (2016). Based on demographic statistics provide by the United Nations, the population of the UAE is 10 million, whereas approximately 7.5 million are above 18 years of age. The statistics for loyalty program membership are not available. Based on previous studies, we note $25 \%$ penetration rate of the loyalty program. The required sample size is 289 . The actual sample consisted of 302 respondents, all of whom belonged to at least one loyalty programbased on collecting points and/or miles. The demographic characteristics are presented in Table 1. 
Kwiatek, P. et al. - Loyalty program value: Give me more or treat me better? - Hotel and Tourism Management, 2021, Vol. 9, No. 2:11-23.

Table 1: Participants' demographic profile

\begin{tabular}{|l|c|c|}
\hline Demographic & $\mathbf{n}$ & \% \\
\hline Gender & & \\
\hline Male & 200 & 66.2 \\
\hline Female & 102 & 33.8 \\
\hline Age & & \\
\hline $18-24$ & 36 & 11.9 \\
\hline $25-29$ & 79 & 26.2 \\
\hline $30-34$ & 84 & 27.8 \\
\hline $35-39$ & 55 & 18.2 \\
\hline $40+$ & 48 & 15.9 \\
\hline Income & & \\
\hline Below \$19,200 & 66 & 21.9 \\
\hline \$19,201-31,980 & 37 & 12.3 \\
\hline \$31,981-63,984 & 58 & 19.2 \\
\hline \$63,985 or above & 74 & 24.5 \\
\hline Not disclosed & 67 & 22.2 \\
\hline Membership tenure & & \\
\hline Less than oneyear & 74 & 33.8 \\
\hline One to two years & 56 & 24.5 \\
\hline Two to three years & 70 & 23.2 \\
\hline More than three years & & \\
\hline
\end{tabular}

Source: Author's res earch 


\section{Results}

We analyze data in Renvironment using psych (Revelle, 2018) and lavaan (Rosseel, 2012) package.

Table 2: Confirmatory factor analys is statistics

\begin{tabular}{|c|c|c|}
\hline & Item & $\bar{\beta}$ \\
\hline \multicolumn{3}{|l|}{ Loyalty Program Economic Value (LPVE; CR = .82; AVE = .60) } \\
\hline 1. Being a member of this Loy alty Program allows me to save money & LPVE1 & 0.81 \\
\hline $\begin{array}{l}\text { 2. Being a member of this Loy alty Program allows me to get more } \\
\text { out of my purchase }\end{array}$ & LPVE2 & 0.73 \\
\hline 3. This Loy alty Program provides good value for money & $\overline{\mathrm{LP}}$ & 0.80 \\
\hline \multicolumn{3}{|l|}{ Loyalty Program Flexibility Value (LPVF; CR = .71; AVE = .46) } \\
\hline 1. What I accumulate in this Loy alty Program will never expire & LPVF1 & 0.80 \\
\hline $\begin{array}{l}\text { 2. The Loyalty Program offers numerous reward redemption } \\
\text { possibilities }\end{array}$ & LPVF2 & 0.78 \\
\hline 3. I feel that members in this Loy alty Program share similar values & LPVF3 & 0.76 \\
\hline \multicolumn{3}{|l|}{ Loyalty Program Social Value (LPVS ; CR $=.84 ;$ AVE $=.63$ ) } \\
\hline $\begin{array}{l}\text { 1. Being a member of this Loy alty Program is like being a member of } \\
\text { a social club }\end{array}$ & LPVS1 & 0.86 \\
\hline 2. This Loy alty Program adds to my identity & LPVS2 & 0.90 \\
\hline $\begin{array}{l}\text { 3. This Loy alty Program makes special offers to earn extra bonuses } \\
\text { (points, miles etc.) }\end{array}$ & LPVS3 & 0.81 \\
\hline \multicolumn{3}{|l|}{ Loyalty Program Recognition Value $(\mathrm{LPVR} ; \mathrm{CR}=.83 ; \mathrm{AVE}=.63)$} \\
\hline 1. I feel special as a member of this Loy alty Program & LPVR1 & 0.83 \\
\hline 2. I receive special treatment as a member of this Loy alty Program & LPVR2 & 0.87 \\
\hline $\begin{array}{l}\text { 3. As a member of this Loy alty Program I get discounts or special } \\
\text { deals other customers don't get }\end{array}$ & LPVR3 & 0.88 \\
\hline \multicolumn{3}{|l|}{ Loyalty $(\mathrm{LOY} ; \alpha=.92 ; \mathrm{CR}=.92 ; \mathrm{AVE}=.60)$} \\
\hline 1. Overall, I am overall satisfied with this Loy alty Program & LOYS3 & 0.83 \\
\hline 2. I enjoy being a member of the Loy alty Program & LOYAC1 & 0.85 \\
\hline $\begin{array}{l}\text { 3. Although there are other loy alty programs I still prefer being a } \\
\text { member of this Loy alty Program }\end{array}$ & LOYAC2 & 0.76 \\
\hline $\begin{array}{l}\text { 4. This Loy alty Program makes me buy more often from particular } \\
\text { brand }\end{array}$ & LOYB1 & 0.76 \\
\hline $\begin{array}{l}\text { 5. I prefer to spend more money buy ing from the company which } \\
\text { runs this Loy alty Program }\end{array}$ & LOYB2 & 0.76 \\
\hline 6. I would recommend my favorite loy alty program to others & LOYR1 & 0.75 \\
\hline 7. I took the opportunity to recommend the loy alty program $\mathrm{t}$ & LOYR2 & 0.79 \\
\hline
\end{tabular}

Note: Model fit: $\chi 2(139)=289.371, \mathrm{p}=.00, \mathrm{CFI}=0.960, \mathrm{TLI}=0.951, \mathrm{RMSEA}=0.060$, $\mathrm{SRMR}=0.036, \mathrm{cmin} / \mathrm{df}=2.19, \mathrm{AVE}=$ average variance extracted; $\mathrm{CR}=$ Cronbach's $\alpha ; \mathrm{CFI}$ = comparative fit index; TLI = Tucker-Lewis index; RMSEA = root mean square error of approximation, $\mathrm{SRMR}=$ standardized root mean square residual

Source: Author's research

All cons truct validity thresholds were satisfying the 0.7 criterion (Fornell \& Larcker, 1981) and ranged from 0.71 (flexibility) to 0.92 (loyalty). Composite reliability was satisfying for 
all constructs, ranging from 0.89 to 0.92 (Nunnally, 1978). Average variance extracted exceeded the 0.5 threshold (Fornell \& Larcker, 1981) for all constructs but flexibility (0.46). The value is accepted based on the rationale that average variance extracted (AVE) is lower than 0.5 , composite reliability is above 0.6 , making the convergent validity of the construct still satis factory (Fornell \& Larcker, 1981). To determine the extent to which variances in the constructs could be explained by the model, $\mathrm{R}^{2}$ values of the dependent constructs were calculated and found to be significant. Loading s for each construct, composite scores, and A VE perconstruct are shown in Table 2 . The convergent validity of the model is established, since all items are significant at 0.05 levels and indicate loadings of 0.6 or higher (Fornell \& Bookstein, 1982).

Table 3: Constructs means and correlations

\begin{tabular}{|l|c|c|c|c|c|c|c|}
\hline Construct & M & SD & $\mathbf{1}$ & $\mathbf{2}$ & $\mathbf{3}$ & $\mathbf{4}$ & $\mathbf{5}$ \\
\hline 1. LPVE & 2.20 & 0.80 & 0.77 & & & & \\
\hline 2. LPVF & 2.20 & 0.70 & 0.79 & 0.68 & & & \\
\hline 3. LPVS & 2.40 & 0.91 & 0.77 & 0.80 & 0.79 & & \\
\hline 4. LPVR & 2.30 & 0.97 & 0.80 & 0.83 & 0.80 & 0.79 & \\
\hline 5. LOY & 2.20 & 0.83 & 0.87 & 0.91 & 0.88 & 0.91 & 0.77 \\
\hline
\end{tabular}

Note: LPVE = Loyalty Program Economic Value; LPVF = Loyalty Program Flexibility Value; LPVS = Loyalty Program Social Value; LPVR = Loyalty Program Recognition Value; LOY = Loyalty; Numbers on the diagonal present square ro ot of AVE

Source: Author's research

In order to test $\mathrm{H} 3$ new scales were created by merging economic and flexibility value into tangible benefits (LPVEF) and social and recognition value into intangible benefits (LPVRS). The new scales were subjected to same analysis and provided satisfactory validity and reliability results. Composite reliability for all three cons tructs exceeded 0.7 threshold and the AVE values ranged from 0.55 to 0.61 . The new model yielded slight decrease in quality but still within acceptable range $(\mathrm{c} 2(146)=332.160, \mathrm{CFI}=0.950$, TLI $=0.942$, $\mathrm{RMSEA}=0.065, \mathrm{SRMR}=0.039, \mathrm{cmin} / \mathrm{df}=2.28)$.

As provided in Table 4, three out five hypotheses are supported by the analys is of the data. First, recognition has the highest impact on customer loy alty $(\beta=0.58, p<0.01)$. The flexibility of a loyalty program (like non-expiring points and numerous redemption possibilities) has significant impact on loyalty $(\beta=0.34, p<0.05)$. Contrary to our expectations, both social value $(\beta=-0.11, p=0.49)$ and economic value $(\beta=0.17, p=0.89)$ have no significantimpact on loyalty. When aggregate measures are used (i.e. tangible and intangible benefits) both are significant. The difference between standardized estimates favors intangible benefits $(\beta$ in $\mathrm{T}-\beta \mathrm{T}=0.02)$ but is marginal. However, we accept the hypothesis $\mathrm{H} 3$ bearing in mind higher value of Wald statistic. 
Table 4: Path results

\begin{tabular}{|l|c|c|l|}
\hline Structural Path & B & $\boldsymbol{z}$ value & Hypothesis \\
\hline LPVS->LOY & -0.11 & 0.49 & H1a not supported \\
\hline LPVR->LOY & 0.58 & $2.81^{* *}$ & H1b supported \\
\hline LPVE->LOY & 0.17 & 0.89 & H2a not supported \\
\hline LPVF->LOY & 0.34 & $2.08^{*}$ & H2b supported \\
\hline LPVSR->LOY & 0.47 & $4.48^{* *}$ & \multirow{2}{*}{ H3 supported } \\
\hline LPVEF->LOY & 0.45 & $4.28^{* *}$ & \\
\cline { 1 - 3 }
\end{tabular}

Note: LPVE = Loyalty Program Economic Value; LPVF = Loyalty Program Flexibility Value; LPVS = Loyalty Program Social Value; LPVR = Loyalty Program Recognition Value; LOY = Loyalty; LPVSR = Intangible Program Value; LPVEF = Tangible Program Value; Paths significant at: * $\mathrm{p}<0.05, * * \mathrm{p}<0.01$

Source: Author's research

\section{Conclusion}

This study extends previous works (Kim et al., 2013; Mimouni-Chaabane \& Volle, 2010; Raab et al., 2016) by simultaneously testing the relationships between focal constructs on LPs. In this respect, it also extends the knowledge on cross-cultural as pects such as of loyalty programs value that concentrated mainly on the Western culture. Previous research was carried out in French (Mimouni-Chaabane \& Volle, 2010) and USA (Kim et al., 2013) cultural contexts. Further, these studies investigated retail and hos pitality industry. To the best of authors' knowledge, the present research study is the first to address the loyalty program's social and recognition value in Arab cultural context, since the current study focused on the sample fromparticipants living in the United Arab Emirates and who are 18 years old and above. The sample included 302 res pondents where they participated in at least one loyalty program.

An LP can be an important driver of company's sales when customers can identify additional value they receive from it (Evanschitzky et al., 2012; Kwiatek \& Thanasi-Boçe, 2019). Loyalty program's perceived value is composed of tangible and intangible elements. Tangible value of a loyalty programis typically depicted by points/miles ratios, discounts, scope and choice of material rewards. Though these types of benefits do influence customer behavior (Meyer-W aarden, 2013) they come at a considerable cost to a sponsoring company. Recognition and social benefits offered to loyalty program members can increase their response at lower cost for a company. For example, material reward needs to be bought in order to be offered. Intangible benefits on the other hand include immaterial benefits like treating customers individually.

In particular, previous research on LPs suggested that social value (feeling of belonging and recognition), and subsequent personalized communication are the drivers of loyalty in collectivist and high-power distance cultures, while monetary rewards are more appealing to individualis tic cultures (Kwiateket al., 2018). Also, cultural elements could be added to the constructs to assess the regional, cultural differences in the value of intangible benefits for LP perception and acceptance by the customers. An important limitation of the present empirical study is its scope. The study focused on a single economy (United Arab Emirates), which could not be seen as a good representative of the Arab countries, due to its stage of development, economy openness, and tourismorientation. Additionally, the research sample is limited quantitatively, and for the future research should be expanded. Finally, the research, due to the respondent level, could not provide focused results in a sense that it could focus on a specific industry. On the other hand, the study reveals several important 
aspects of LP programs in an Arab country. Firstly, the study confirmed that social value of a loyalty programsignificantly impacts customer loyalty. Secondly, it was confirmed that the flexibility of a loyalty program among consumers in the UAE plays important role in enhancing their loyalty. Finally, and most importantly, it was confirmed that customers value intangible benefits to a greater extent than the tangible ones, which brings back the notion of importance of investing in customer capital.

\section{Conflict of interest}

The authors declare no conflict of interest.

\section{References}

1. Alshurideh, M., Gasaymeh, A., Ahmed, G., Alzoubi, H., \& Kurd, B. (2020). Loyalty program effectiveness: Theoretical reviews and practical proofs. Uncertain Supply Chain Management, 8(3), 599-612. https://doi.org/10.5267/j.uscm.2020.2.003

2. Altinay, L., \& Taheri, B. (2019). Emerging themes and theories in the sharing economy: A critical note for hospitality and tourism. International Journal of Contemporary Hospitality Management.31(1), 180-193. https://doi.org/10.1108/IJCHM-02-2018-0171

3. Arora, P., \& Narula, S. (2018). Linkages between service quality, customer satis faction and customer loyalty: A literature review. IUP Journal of Marketing Management, 17(4), 30-53.

4. Baloglu, S. (2002). Dimensions of customer loyalty: Separating friends from well wishers. Cornell Hotel and Restaurant Administration Quarterly, 43(1), 47-59. https://doi.org/10.1177/0010880402431005

5. Blau, P. M. (1964). Justice in social exchange. Sociological Inquiry, 34(2), 193-206. https://doi.org/10.1111/j.1475-682X.1964.tb00583.x

6. Bolton, R. N., Lemon, K. N., \& Verhoef, P. C. (2004). The theoretical underpinnings of customer asset management: A framework and propositions for future research. Journal of the Academy of Marketing Science, 32(3), 271-292. https://doi.org/10.1177/0092070304263341

7. Bontis, N., Janoš ević, S., \& Dženopoljac, V. (2015). Intellectual capital in Serbia's hotel indu stry. International Journal of Contemporary Hospitality Management, 27(6), 1365 1384. https://doi.org/10.1108/IJCHM-12-2013-0541

8. Brashear-Alejandro, T., Kang, J., \& Groza, M. D. (2016). Leveraging loyalty programs to build customer-company identification. Journal of Business Research, 69(3), 1190 1198. https://doi.org/10.1016/j.jbus res.2015.09.014

9. Buhalis, D., \& Volchek, K. (2021). Bridging marketing theory and big data analytics : The taxonomy of marketing attribution. International Journal of Information Management, 56, 102253. https://doi.org/10.1016/j.ijinfomgt.2020.102253

10. Chen, Y., Mandler, T., \& Meyer-Waarden, L. (2021). Three decades of research on loyalty programs: A literature review and future research agenda. Journal of Business Research, 124, 179-197. https://doi.org/10.1016/j.jbus res.2020.11.057

11. Dewitte, M., Mallargé, J., \& Decrop, A. (2021). Consumer perception of service quality: The case of Airbnb and Couchsurfing. In Decrop, A., Correia, A., Fyall, A., \& Kozak, M. (Eds.), Sustainable and Collaborative Tourism in a Digital World, Oxford: Goodfellow Publishers.

12. Drèze, X., \& Nunes, J. C. (2011). Recurring goals and learning: The impact of successful reward attainment on purchase behavior. Journal of Marketing Research, 48(2), 268-281. https ://doi.org/10.1509/jmkr.48.2.268 
13. Evanschitzky, H., Ramaseshan, B., Wois etschläger, D. M., Richelsen, V., Blut, M., \& Backhaus, C. (2012). Consequences of customer loyalty to the loyalty program and to the company. Journal of the Academy of Marketing Science, 40(5), 625-638. https://doi.org/10.1007/s 11747-011-0272-3

14. Fornell, C., \& Bookstein, F. L. (1982). Two structural equation models: LISREL and PLS applied to consumer exit-voice theory. Journal of Marketing Research, 19(4), 440 452. https://doi.org/10.1177/002224378201900406

15. Fornell, C., \& Larcker, D. F. (1981). Evaluating structural equation models with unobservable variables and measurement error. Journal of Marketing Research, 18(1), 39-50. https://doi.org/10.1177/002224378101800104

16. Gunay, S., Dzenopoljac, V., \& Bontis, N. (2021). Social media as a proxy for intellectual capital: Twitter pos ts in the cryptocurrency market. International Journal of Web Based Communities, forthcoming.

17. Ha, S., \& Stoel, L. (2014). Designing loyalty programs that matter to customers. The Service Industries Journal, 34(6), 495-514. https://doi.org/10.1080/02642069.2014.871531

18. Hennig-Thurau, T., Gwinner, K. P., \& Gremler, D. D. (2002). Understanding relationship marketing outcomes: An integration of relational benefits and relationship quality. Journal of Service Research, 4(3), 230-247. https://doi.org/10.1177/1094670502004003006

19. Hollebeek, L. D., Das, K., \& Shukla, Y. (2021). Game on! How gamified loyalty programs boost customer engagement value. International Journal of Information Management, 102308. https://doi.org/10.1016/j.ijinfomgt.2021.102308

20. Homans, G. C. (1961). Social Behavior: Its Elementary Forms. New York, Harcourt: Brace \& World.

21. Jevtić, J., Tomić, S., \& Leković, K. (2020). Customer experience in the tourism industry-Determinants influencing complaint behaviour. Menadžment u hotelijerstvu $i$ turizmu - Hotel and Tourism Management, 8(2), 25-33. https://doi.org/10.5937/menhottur2002025J

22. Kim, H.-Y., Lee, J. Y., Choi, D., Wu, J., \& Johns on, K. K. (2013). Perceived benefits of retail loyalty programs: Their effects on programloy alty and customer loyalty. Journal of Relationship Marketing, 12(2), 95-113. https://doi.org/10.1080/15332667.2013.794100

23. Kim, J. J., Steinhoff, L., \& Palmatier, R. W. (2021). An emerging theory of loyalty program dynamics. Journal of the Academy of Marketing Science, 49(1), 71-95. https ://doi.org/10.1007/s 11747-020-00719-1

24. Kopalle, P. K., Sun, Y., Neslin, S. A., Sun, B., \& Swaminathan, V. (2012). The joint sales impact of frequency reward and customer tier components of loy alty programs. Marketing Science, 31(2), 216-235. https://doi.org/10.1287/mksc.1110.0687

25. Kuhzady, S., Olya, H., Farmaki, A., \& Ertaş, Ç. (2021). Sharing economy in hospitality and tourism: a review and the future pathways. Journal of Hospitality Marketing \& Management, 1-22. https://doi.org/10.1080/19368623.2021.1867281

26. Kwiatek, P., Morgan, Z., \& Baltezarevic, R. (2018). Actions speak louder than words: Unders tanding the meaning of loyalty programbuilding blocks. Economics \& Sociology, 11(2), 305-319. https://doi.org/10.14254/2071-789X.2018/11-2/21

27. Kwiatek, P., \& Thanasi-Boçe, M. (2019). Loyalty program activity: Make B2B customers buy more. Marketing Intelligence \& Planning, 37(5), 542-554. https://doi.org/10.1108/MIP-06-2018-0193

28. Lentz, M., Berezan, O., \& Raab, C. (2021). Uncovering the relationship between revenue management and hotel loyalty programs. Journal of Revenue and Pricing Management, 1-15. https://doi.org/10.1057/s 41272-021-00331-0 
29. Lima, S., \& de Assis Carlos Filho, F. (2019). Bibliometric analysis of scientific production on sharing economy. Revista de Gestão, 26(3), 237-255. https://doi.org/10.1108/REGE-01-2019-0018

30. Liu, Y. (2007). The long-term impact of loyalty programs on consumer purchase behavior and loyalty. Journal of Marketing, 71(4), 19-35. https://doi.org/10.1509/jmkg.71.4.019

31. Melancon, J. P., Noble, S. M., \& Noble, C. H. (2011). Managing rewards to enhance relational worth. Journal of the Academy of Marketing Science, 39(3), 341-362. https://doi.org/10.1007/s 11747-010-0206-5

32. Meyer-Waarden, L. (2013). The impact of reward personalisation on frequent flyer programmes' perceived value and loyalty. Journal of Services Marketing, 27(3), 183194. https://doi.org/10.1108/08876041311330681

33. Mimouni-Chaabane, A., \& Volle, P. (2010). Perceived benefits of loyalty programs: Scale development and implications for relational strategies. Journal of Business Research, 63(1), 32-37. https://doi.org/10.1016/j.jbusres.2009.01.008

34. Nesset, E., Bergem, O., Nervik, B., Sørlie, E. S., \& Helgesen, Ø. (2021). Building chain loyalty in grocery retailing by means of loyalty programs - A study of 'the Norwegian case'. Journal of Retailing and Consumer Services, 60, 102450. https://doi.org/10.1016/j.jretconser.2021.102450

35. Nunnally, J. C. (1978). Psychometric Theory (2nd ed.). McGraw-Hill.

36. O'Brien, L., \& Jones, C. (1995). Do rewards really create loyalty? Long Range Planning, 28(4), 130-130.

37. O'Connor, P. (2021). Loyalty programs and direct website performance: An empirical analysis of global hotel brands. Information and Communication Technologies in Tourism 2021 (pp. 150-161). Springer. https://doi.org/10.1007/978-3-030-65785-7_13

38. Omar, N. A., Wel, C. A. C., Musa, R., \& Nazri, M. A. (2010). Program benefits, satis faction and loyalty in retail loyalty program: Exploring the roles of program trust and program commitment. IUP Journal of Marketing Management, 9(4), 6-28.

39. Pascual, M. E., \& Cain, L. N. (2021). Loyalty programs: The vital safety feature for airlines to survive COVID-19. International Hospitality Review. https://doi.org/10.1108/IHR-03-2021-0017

40. Premayani, W., Ayu, I., Giantari, K., \& Kerti, N. (2018). The effect of self image congruity and functional congruity to attitudes and repurchase intention. IOSR Journal of Business and Management, 20, 8-11. https ://doi.org/10.9790/487X-2002070811

41. Raab, C., Berezan, O., Krishen, A. S., \& Tanford, S. (2016). What's in a word? Building programloyalty through social media communication. Cornell Hospitality Quarterly, 57(2), 138-149. https://doi.org/10.1177/1938965515619488

42. Revelle, W. (2018). Psych: procedures for personality and psychological research. Evanston: Northwestern University.

43. Rosseel, Y. (2012). Lavaan: An R package for structural equation modeling and more. Version 0.5-12 (BETA). Journal of Statistical Software, 48(2), 1-36.

44. Satti,Z. W., Babar, S. F., Parveen, S., Abrar, K., \& Shabbir, A. (2020). Innovations for potential entrepreneurs in service quality and customer loyalty in the hospitality industry. Asia Pacific Journal of Innovation and Entrepreneurship, 14(3), 317-328. https://doi.org/10.1108/APJIE-08-2019-0063

45. Sigala, M. (2017). Collaborative commerce in touris m: Implications for research and industry. Current Issues in Tourism, 20(4), 346-355. https://doi.org/10.1080/13683500.2014.982522

46. So, J. T., Danaher, T., \& Gupta, S. (2015). What docustomers get and give in return for loyalty programmembers hip? Australasian Marketing Journal (AMJ), 23(3), 196-206. https://doi.org/10.1016/j.aus mj.2015.02.002 
47. Steinhoff, L., \& Palmatier, R. W. (2016). Understanding loyalty program effectivenes s: managing target and bystander effects. Journal of the Academy of Marketing Science, 44(1), 88-107. https://doi.org/10.1007/s 11747-014-0405-6

48. Tanford, S. (2013). The impact of tier level on attitudinal and behavioral loy alty of hotel reward programmembers. International Journal of Hospitality Management, 34, 285 294. https://doi.org/10.1016/j.ijhm.2013.04.006

49. Umashankar, N., Bhagwat, Y., \& Kumar, V. (2017). Do loyal customers really pay more for services? Journal of the Academy of Marketing Science, 45(6), 807-826. https://doi.org/10.1007/s 11747-016-0491-8

50. Uncles, M. D., Dowling, G. R., \& Hammond, K. (2003). Customer loy alty and customer loyalty programs. Journal of Consumer Marketing, 20(4), 294-316. https://doi.org/10.1108/07363760310483676

51. Vujić, M., Đorđević, S., \& Lakićević, M. (2019). Service quality and customer satis faction in the hotel industry in Serbia. Menadžment u hotelijerstvu i turizmu-Hotel and Tourism Management, 7(1), 61-70. https://doi.org/10.5937/menhottur1901061V

52. Xiong, L., King, C., \& Hu, C. (2014). Where is the love? Investigating multiple membership and hotel customer loyalty. International Journal of Contemporary Hospitality Management, 26(4), 572-592. https://doi.org/10.1108/IJCHM-03-2013-0141

53. Yi, Y., \& Jeon, H. (2003). Effects of loyalty programs on value perception, program loyalty, and brand loyalty. Journal of the Academy of Marketing Science, 31(3), 229 240. https://doi.org/10.1177/0092070303031003002

54. Zakaria, I., Rahman, B. A., Othman, A. K., Yunus, N. A. M., Dzulkipli, M. R., \& Osman, M. A. F. (2014). The relationship between loyalty program, customer satisfaction and customer loy alty in retail industry: A case study. Procedia-Social and Behavioral Sciences, 129, 23-30. https://doi.org/10.1016/j.sbspro.2014.03.643 